\title{
Quality of Life in Patients with Acute Stroke: Comparison Between the Short Form 36 and the Stroke-Specific Quality of Life Scale
}

\author{
Akut İnmeli Hastalarda Yaşam Kalitesi: Kısa Form 36 ve İnmeye Özgü Yaşam Kalitesi \\ Ölçeği Karşılaştırması
}

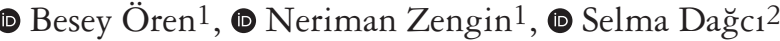 \\ 1 University of Health Sciences Turkey, Hamidiye Faculty of Health Sciences, Department of Midwifery, Istanbul, Turkey \\ 2Istanbul Provincial Health Directorate, Department of Public Hospitals Service-2, Istanbul, Turkey
}

\begin{abstract}
Objective: The aim of the study was to compare the Turkish version of the Stroke Specific Quality of Life Scales (SS-QOL) and the Short Form-36 (SF-36) Scale used to determine the health-related quality of life (HRQoL) of patients with stroke, to evaluate the effectiveness of both scales, and to determine whether these two scales differed according to sociodemographic characteristics in patients with stroke. HRQoL measurements are commonly used to quantify disease burden, to evaluate treatment method, and to facilitate benchmarking. The study had a descriptive and methodologic design.

Materials and Methods: This study was conducted with 205 patients who were hospitalized with the diagnosis of stroke and followed up for at least 48 hours in a neurology department of a hospital in Istanbul. The data of the study were collected using a form including 18 questions related to sociodemographic characteristics of the patients and the disease, and the SF-36 and SS-QOL scales. In the analysis of data, in addition to descriptive statistical methods, the KruskalWallis test, Mann-Whitney U test, and Spearman's correlation analysis were used. Significance was evaluated at $\mathrm{p}<0.05$. Approval of the institutional ethics committee was obtained.

Results: The mean age of the study group was $65.23 \pm 13.64$ years. The study group consisted of primary school graduates $(46.6 \%)$, married $(75 \%)$, and unemployed $(84.9 \%)$ patients. It was observed that the mean scores of SF-36 and SS-QOL subdimensions-apart from mental health-mood subdimensions-were higher than those of the SS-QOL, and both scales had higher internal consistencies, ranging between 0.74-0.97 for SS-QOL and 0.59-0.95 for SF-36. Also, there was a positive, and statistically significant correlation between the dimensions of the scales $(\mathrm{p}<0.05)$, and a moderate correlation existed between similar subdimensions ( $\mathrm{r}=0.042-0.59)$.

Conclusion: Both scales can be used to evaluate the quality of life of patients with acute stroke. However, SS-QOL is recommended as a priority for patients with acute stroke.
\end{abstract}

Keywords: HRQoL, neurology nursing, stroke, SS-QOL, SF-36, quality of life

Öz

Amaç: Bu çalışma inme hastalarının sağlıkla ilgili yaşam kalitelerini (HRQoL) belirlemek amacıyla çalışmalarda sıklıkla kullanılan İnmeye Özgü Yaşam Kalitesi Ölç̧ӗi (SS-QOL) ile daha az sayıda kullanılan Kısa Form (SF-36) ölçeklerinin Türkçe formlarını karşılaştırmak, her iki ölçeğin etkinliğini değerlendirmek ve bu iki ölçeğin inmeli hastalarda sosyodemografik özelliklere göre farklılık gösterip göstermediğini incelemek amacıyla yapıldı.

Gereç ve Yöntem: Tanımlayıcı ve kesitsel olarak yapılan çalışma İstanbul'daki bir hastanenin nöroloji servisinde inme tanısı ile yatan, en az 48 saat takip edilen 205 hasta ile gerçekleştirildi. Araştırmanın verileri 18 sorudan oluşan sosyodemografik ve hastalıkla ilgili soru formu, SF-36 ve SS-QOL aracılığıyla, olgularla yüz yüze görüşme tekniği ile ve bir uzman hemşire tarafından toplandı. Verilerin analizinde; tanımlayıcı istatistiksel metodların (ortalama, standart sapma, frekans) yanı sıra niceliksel verilerin karşılaştırılmasında üç ve üzeri gruplarda Kruskal-Wallis testi, ikili grupların karşılaştırılmasında Mann-Whitney U test kullanıldı. Parametreler arasındaki ilişkilerin incelenmesinde Spearman korelasyon analizi kullanıldı. Anlamlılık p $<0,05$ düzeyinde değerlendirildi. Kurumdan etik kurul izni alındi.

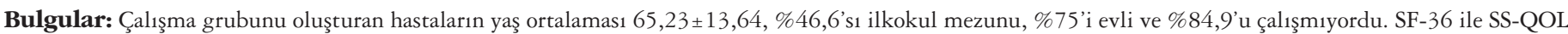
ölçeğinin benzer alt boyut puan ortalamalarını mental sağlık-duygu durum dışındaki alt boyutlarda SS-QOL'nin puan ortalamalarının daha yüksek olduğu, her iki

Address for Correspondence/Yazışma Adresi: Besey Ören MD, University of Health Sciences Turkey, Hamidiye Faculty of Health Sciences, Department of Midwifery, Istanbul, Turkey

Phone: +90 5327756206 E-mail: besey_oren@yahoo.com ORCID: orcid.org/0000-0003-4182-7226

Received/Geliş Tarihi: 08.10 .2019 Accepted/Kabul Tarihi: 26.08 .2020

${ }^{\circ}$ Copyright 2020 by Turkish Neurological Society

Turkish Journal of Neurology published by Galenos Publishing House. 


\section{Öz}

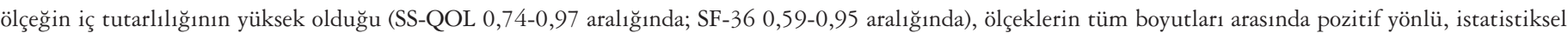

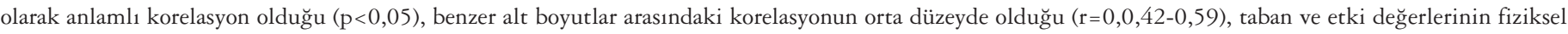
fonksiyon ve aktivite hariç benzer olduğu görüldü.

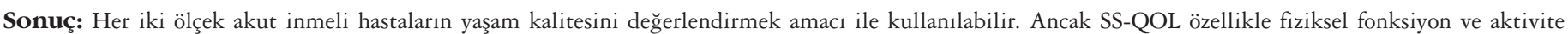
bakımından daha objektif sonuçlar verebileceğinden akut inmeli hastalar için önerilir.

Anahtar Kelimeler: HRQoL, nöroloji hemşireliği, inme, SS-QOL, SF-36, yaşam kalitesi

\section{Introduction}

Stroke is a major public health problem that affects both the short- and long-term quality of life (QoL) of patients and is one of the top-ranked diseases leading to serious mortality and morbidity (1). In 2012 World Health Organization (WHO) defined stroke as "a clinical syndrome consisting of rapidly developing clinical signs of focal (or global in case of coma) disturbance of cerebral functions lasting more than 24 hours or leading to death with no apparent cause other than a vascular origin".

According to WHO 2012 data, every year 15 million people have a stroke, causing permanent damage in 5 million of them. It is the third leading cause of death worldwide after coronary heart disease and cancer $(1,2)$. Irrespective of heart diseases, it ranks $5^{\text {th }}$ among causes of death (3). It has been reported that the incidence of stroke in Turkey is 175 per 100 thousand people (4) and it is among the top 10 causes of death seen in all age groups (5).

Acute stroke has devastating effects on both the patient and their family. It exerts many negative effects on patients including physical dysfunction, cognitive disorders and an inability to perform activities of daily life (6). It is the leading cause of motor handicap, the second prominent cause of dementia, and the third foremost cause of death (7).

Patients with stroke are faced with many physical, mental, social and economic handicaps during their lifetime (8). Patients experience restrictions in their functional independence and social relationships and are forced to make changes in their personal, social, and professional goals in order to deal with the symptoms of the disease, to maintain self-care, and to adapt to changes in their body images. As a result, these handicaps impose an adverse effect onthe QoL of these patients (9). Health-related quality of life (HRQoL) focuses on the impact of an individual's perceived health status $(10,11)$.

\section{Background}

HRQoL is considered as an important outcome measure and aims to measure how the individual's functions are affected by the disease and changes in their functions. These subdimensions usually determine whether there is a lack of physical, psychological or social functions (SF) (8).

It is useful to determine HRQoL in order to specify health care and treatment strategies, to make patient-specific planning, and to evaluate the effectiveness of health care and treatment (12). Many bodily functions of patients with stroke are adversely affected, and therefore evaluation of the QoL in patients with stroke carries utmost importance.

The concept of QoL is defined as multidimensional, including physical, psychologic/spiritual, and socio-economic well-being (13). QoL is a complex concept involving highly subjective parameters and there is no common measurement tool. Although there are approximately 5.000 disease-specific generic scales, a universal scale for QoL assessment is lacking (7).

HRQoL instruments are widely used to measure disease burden, to assess treatment modality, and to facilitate comparative evaluations (14). Subjective effects of stroke cannot be evaluated by objective measurement tools. For this reason, the HRQoL of patients with stroke is evaluated using many measurement tools that assess subjective well-being, and have been widely employed in the evaluation of the state of health of patients in recent years $(8,15,16)$.

Generic or specifically standardized scales are being used to evaluate objective QoL in stroke. The most common generic QoL scales used in stroke are the Nottingham Health Profile and short form-36 (SF-36). However, disease-specific scales developed in recent years have been frequently used in studies to assess the QoL of these patients (17). In studies where strokerelated QoL has been evaluated, the disease-specific Stroke Specific Quality of Life Scales (SS-QOL) scale has been used frequently $(9,18,19,20,21)$. It has been reported that assessments made with disease-specific scales measure the patient's physical functions (PF) and well-being better than generic scales because they have been prepared considering the symptoms of the disease so as to obtain more specific measurement results $(17,22)$.

The SF-36 and SS-QOL scales were used together in validity studies (9) and patients with aneurysmal subarachnoid hemorrhage for the purpose of comparative evaluation (14). However, we have not encountered any study that compared the SS-QOL with other similar scales in patients with stroke. This study was performed to compare the Turkish version of the SS-QOL and the less frequently used SF-36 scales to determine HRQoL in patients with stroke, to evaluate the effectiveness of both scales, and to assess whether these two scales differed according to sociodemographic characteristics of patients with stroke.

\section{Materials and Methods}

\section{The Aim of the Study}

A descriptive and cross-sectional study was performed to evaluate the HRQoL of patients with stroke, to compare the SF36, which is one of the globally used QoL scales, with the SS-QOL, to investigate the relationship between them, and inquire whether they differed according to sociodemographic characteristics of the patients. The definition of stroke proposed by the WHO was used for the study. 


\section{Hypothesis}

We assumed that the SF-36 and SS-QOL would show similar sensitivities on the basis of their similar subdimensions. These subdimensions are PF, SF, vitality (VT), and mental health $(\mathrm{MH})$ for SF-36, and physical activities, social and family roles, energy, and mood for the SS-QOL.

\section{Study Population}

The study population consisted of all patients admitted to the neurology department of a training and research hospital in Istanbul between July 2014 and December 2015. During the study period, 514 patients were admitted to the neurology ward with a diagnosis of stroke. Of these patients, 12 died, 53 were transferred to other wards, and 85 refused to participate in the study. Among the 364 patients who were followed up in the ward and agreed to participate in the study, 205 cases who met the study criteria were included in the study. Literate patients aged over 18 years without mental retardation who were being followed up for at least 48 hours and agreed to participate in the survey comprised the study population.

Aphasic patients, those with visual and hearing impairments with whom the exchange of information was impossible, and patients with musculoskeletal and nervous system disorders other than stroke (developmental hip dysplasia, advanced osteoarthritis, rheumatoid arthritis, ankylosing spondylitis, amputation, myasthenia gravis, Parkinson's disease) were not included in the study.

\section{Data Collection Instruments}

The data of the study were collected using the SF-36 scale comprising 18 questions related to the sociodemographic characteristics of the patients and the SS-QOL via face-to-face interviews with the patients performed by a qualified nurse.

Sociodemographic and disease-specific characteristics of the patients including, sex, educational status, marital status, and working status were questioned. Among the characteristics of the disease, the presence of post-stroke sequalae and additional disease(s) were inquired.

\section{Short Form-36}

The SF-36 is the best-known and the most widely used HRQoL scale in healthcare research. It has been reported that it can be used to evaluate QoL in patients with physical illness $(23,24)$.

The scale was developed by Ware and Sherbourne (25) in 1987 to assess overall QoL in healthy and ill individuals. The validity and reliability assessments of its Turkish version were made by Pinar (26) in 1995. The scale consists of 36 items, two main (physical and mental), and eight subdimensions. The subdimensions of the scale were: (1) PF, (2) role limitation due to physical problems, (3) SF, (4) role limitation due to emotional problems, (5) $\mathrm{MH}$, (6) VT, (7) bodily pain and (8) general health perception. In total and subdimensions, the scale score ranges from 0 to 100 , and the increase in the score of each health subdimension indicates a positive increase in HRQoL. In the study of Pinar (26), the test-re test value of the SF-36 was found as 0.94 and the Cronbach's alpha value of internal consistency was 0.91. In our study, Cronbach's alpha values of the subdimensions ranged from 0.59 to 0.97 .

\section{Stroke-Specific Quality of Life Scale}

This Stroke- Specific Quality of Life Scale was developed by Williams et al. (21). The SS-QOL consists of 49 items and 12 subdimensions (mobility, VT, upper extremity functioning, work/ productivity, mood, self-care, social roles, family roles, language $(\mathrm{L})$, vision $(\mathrm{V})$, thinking $(\mathrm{T})$ and personality $(\mathrm{P})$, which are rated using a 5-point Likert-type scale ( $1=\mathrm{I}$ totally agree, $2=\mathrm{I}$ partially agree, $3=\mathrm{I}$ neither agree nor disagree, $4=\mathrm{I}$ partially disagree, $5=\mathrm{I}$ disagree) taking the previous week into consideration (21). The scale was adapted into Turkish by 27 . Hakverdioğlu and Khorshid (27) in 2009. In its Turkish version, in the factor analysis, different from the original version, 49 items were composed of 8 subdimensions (activities, social and family roles, L, V, VT, mood, $\mathrm{P}, \mathrm{T})$ (27). In the evaluation, total score, and the score of each subdimension are obtained. The higher the score, the better is the quality of life of patients with stroke. The total Cronbach's alpha value of the Turkish version of the scale was 0.97. In our study, Cronbach's alpha values for the subdimensions ranged between $0.73(\mathrm{P} / \mathrm{T})$ and 0.96 (energy).

\section{Statistical Analysis}

When evaluating the findings obtained in this study, the IBM SPSS Statistics 22 for statistical analysis (SPSS IBM, Turkey) software program was used. The SS-QOL scale scores were converted to percentile scores for comparison with the SF-36 scores. The prevalence of the lowest ("floor" effect) and highest ("ceiling" effect) possible QoL scores in the SS-QOL and SF-36 were also calculated. The difference between the distributions of ceiling and floor scores was examined using the chi-square test. The conformity of the data to normal distribution was evaluated using the Shapiro-Wilk test. In addition to the descriptive statistical methods (mean, standard deviation, frequency), the Kruskal-Wallis test was used for the comparison of quantitative data, and the Mann-Whitney U test was used for the comparison of the two groups. Spearman's correlation analysis was employed to examine relationships between the parameters. Significance was evaluated at $\mathrm{p}<0.05$.

\section{Ethical Dimension}

Priorly, approval of the Ethics Committee of Umraniye Training and Research Hospital was acquired (B.10.10TKH.4.34.H.GP.0.01/43) and the purpose of the study was explained to the participants before their informed written consent was obtained. The Helsinki Declaration of Human Rights was followed.

\section{Results}

The mean age of the study group was $65.23 \pm 13.64$ years. The group consisted of primary school graduates (46.6\%), married $(75 \%)$, and unemployed $(84.9 \%)$ patients, and $64.4 \%$ of the participants were from middle-income families (Table 1).

Total and Subscale Scores of Similar Subdimensions of SF-36 and SS-QOL Scales

The mean scores of the PF, SF, VT, MH subdimensions of the SF-36 scale were as follows: $42.37 \pm 34.37,52.07 \pm 31.02$, $45.24 \pm 22.50$, and $62.30 \pm 19.41$, respectively. The mean scores of the subdimensions of SS-QOL, including PA, SFR, E, and M, were $62.25 \pm 24.81,56.08 \pm 26.20,53.66 \pm 27.33$, and $61.85 \pm 26.25$, 
respectively. When the similar subdimensions of the scales were examined, it was seen that the mean scores of the SF-36 subdimensions were lower relative to the SS-QOL mean scores except for the subdimensions of $\mathrm{MH}-\mathrm{M}$. Mean $\mathrm{MH}-\mathrm{M}$ scores of both scales $(62.30+19.41$ vs $61.85,26.26)$ were very similar.

Cronbach's Alpha Coefficients of the SS-QOL and the SF36 Scales

Cronbach's alpha coefficients for SS-QOL and SF-36 scales ranged from 0.74 to 0.97 , and from 0,59 to 0.95 , respectively, which supports the presence of a robust internal consistency. When the similar subdimensions of the scales were examined, it was seen that the Cronbach's alpha coefficient of SF-36 was lower than that of SS-QOL ( $\mathrm{SF}<\mathrm{SFR}, \mathrm{VT}<\mathrm{E}, \mathrm{MH}<\mathrm{M}$ ). Cronbach's alpha coefficient of SF-36 was found to be 0.70 in three subdimensions (VT, SF, MH). However, the Cronbach's alpha coefficient of the SS-QOL scale was $>0.74$ in all subscales (Table 2 ).

Floor Effects and Ceiling Effects for the SS-QOL and the SF-36 Scales

Table 2 and Graph 1 show the distributions of floor effect rates of both scales. When the lowest scores of both scales were compared, no significant difference was observed between the distribution in dimensions of PF-PA (20-2.9\%; $\mathrm{p}=0.096)$, VT-E (1.5-15.1\%; $\mathrm{p}=0.39)$ subdimensions $(\mathrm{p}>0.05)$, whereas the floor effect rates of SF-SFR (9.8-12.2\%; $<<0.001$ respectively), MH-M $(0-7.5 \% ; \mathrm{p}=0.005)$ were found to be statistically significantly

\begin{tabular}{|c|c|c|c|}
\hline & & $\mathrm{n}$ & $\%$ \\
\hline \multicolumn{2}{|l|}{$\begin{array}{l}\text { Age (years) min } \\
-\max , \text { mean } \pm \\
S D(n=203)\end{array}$} & $19-94$ & $65.23 \pm 13.64$ \\
\hline \multirow{2}{*}{ Sex } & Female & 90 & 43.9 \\
\hline & Male & 115 & 56.1 \\
\hline \multirow{7}{*}{$\begin{array}{l}\text { Educational } \\
\text { status }(n=204)\end{array}$} & Illiterate & 45 & 22.1 \\
\hline & Literate & 15 & 7.4 \\
\hline & Primary school & 95 & 46.6 \\
\hline & $\begin{array}{l}\text { Secondary } \\
\text { school }\end{array}$ & 22 & 10.8 \\
\hline & Lycée & 18 & 8.8 \\
\hline & $\begin{array}{l}\text { High school/ } \\
\text { university }\end{array}$ & 8 & 3.9 \\
\hline & Other & 1 & 0.5 \\
\hline \multirow{2}{*}{$\begin{array}{l}\text { Marital status } \\
(n=200)\end{array}$} & Single & 50 & 25 \\
\hline & Married & 150 & 75 \\
\hline \multirow{2}{*}{ Working status } & Employed & 31 & 15.1 \\
\hline & Unemployed & 174 & 84.9 \\
\hline \multirow{4}{*}{ Income level } & Very low & 12 & 5.9 \\
\hline & Low & 22 & 10.7 \\
\hline & Middle & 132 & 64.4 \\
\hline & High & 39 & 19 \\
\hline
\end{tabular}

different. When ceiling effect rates of scales were compared PFPA (5.4-5.9\%; $\mathrm{p}=0.02)$, SF-SFR (13.2-8.8\%; $\mathrm{p}=0.004)$, VT-E (2.4-13.7\%; $\mathrm{p}=0.019$, respectively), no statistically significant difference was found between the distributions of $\mathrm{MH}-\mathrm{M}$ (2.0$13.2 \% ; \mathrm{p}=0.437$, respectively).

The relationship between the subdimensions of the scales is shown in Table 3. A statistically significant correlation was found between SF-36 and all dimensions of the SS-QOL scale $(0.21 \leq$ $\mathrm{r} \leq 0.59 ; \mathrm{p}<0.01)$. A moderate correlation was detected between similar subdimensions $(r=0.428-0.59)$. The strongest and the weakest correlations were detected between subdimensions of PF-PA $(\mathrm{r}=0.59, \mathrm{p}<0.05)$ and MH-M $(\mathrm{r}=0.042, \mathrm{p}<0.05)$, respectively.

The comparison of the SS-QOL and the SF-36 subdimensions according to sociodemographic characteristics. The four subdimensions of the SF-36 and SS-QOL scales (SF-36: PF, VT, MH, SF; SS-QOL: activities, energy, mood, social and family roles) were compared in terms of demographic and disease-related data. A statistically significant difference was found between indicated subdimensions as for age (PF/PA, VT/E), sex (PF/PA), educational levels (PF/PA), working status $(\mathrm{MH} / \mathrm{M})$ of the patients, and poststroke sequelae (PF/PA, VT/E, MH/M, SF/SFR). Relatively higher quality of life scores were detected in younger patients in the subdimensions of physical activity, and energy, in male patients, and lycée graduates $(\mathrm{p}<0.05)$ (Table 4).

Both scales showed significant differences in different subdimensions according to demographic characteristics. When compared with the SS-QOL, statistically significant differences were seen in indicated subdimensions of SF-36 regarding age (SF), educational level (VT), and working status (PF, VT, and SF). The SS-QOL differed statistically significantly from SF-36 with respect to educational status (E) included in socio-demographic characteristics $(\mathrm{p}<0.05)$ (Table 4).

When overall QoL was evaluated using the SF-36, it was seen that QoL scores were better in young people and men regarding $\mathrm{SF}$, college graduates demonstrated higher scores in energy, and employees in domains of physical and SF. When QoL was evaluated using the SS-QOL scale, it was seen that lycée graduates received more favourable scores in energy subdimension.

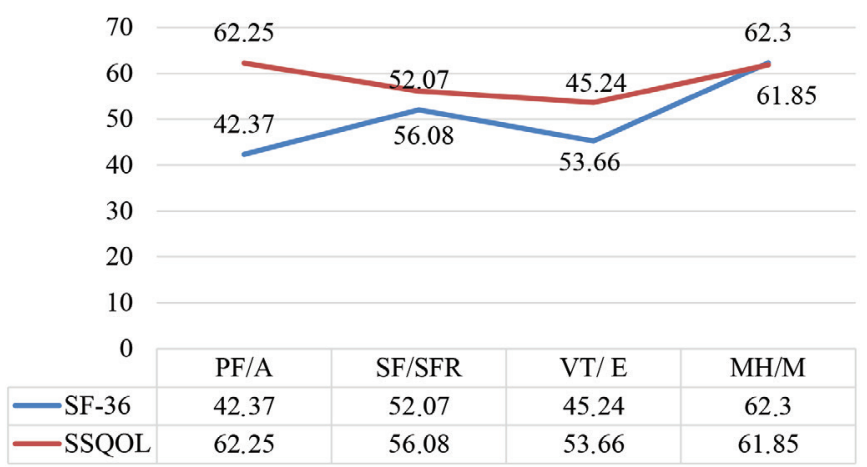

Graph 1. Floor and ceiling effect rates of similar dimensions of SF-36 and SS-QOL scales

SF-36: Short form-36, SS-QOL: Stroke Specific Quality of Life Scale, PF: Physical functioning, SF: Social functioning, PA: Physical activity, SFR: Social family roles, E: Energy, M: Mood, VT: Vitality, MH: Mental health 


\section{Discussion}

The aim of this study was to compare the SF-36, which was developed specifically for stroke in patients with acute stroke and to compare the sociodemographic characteristics of patients with stroke with similar subdimensions. It was concluded that both instruments were useful in determining QoL in patients with acute stroke. Both scales have been used for evaluating HRQoL in different populations. There are numerous studies where the two scales were used for evaluating HRQoL $(7,13,14,16,17)$. Some validity and reliability studies have used two scales in combination (9). However, as far as we know, this is the first study to compare both scales in patients with acute stroke.

\section{Assessment of Floor and Ceiling Scores of Scales}

Lower percentages of floor and ceiling scores and highreliability criteria indicate that the measurement was performed well $(28,29)$. A percentage greater than $20 \%$ indicates a significant floor/ceiling effect $(22,30)$. In our study, SS-QOL ceiling score percentages were higher; however, floor score rates were higher in three subdimensions of the SF-36, except for PF/PA. These findings may be because although they are similar, these subdimensions do not evaluate the same structure and that SF-36 evaluates both the positive and negative aspects of health. However, the SS-QOL assesses these post-stroke functions in more detail (12). In the Turkish version of the SS-QOL, the PA subdimension

Table 2. The distribution of the SF-36 and the SS-QOL dimensions, Cronbach's alpha values, floor and ceiling effect rates

\begin{tabular}{|c|c|c|c|c|c|c|c|c|}
\hline $\begin{array}{l}\text { SF-36 } \\
\text { SS_QOL }\end{array}$ & Mean & Median & Range & $\begin{array}{l}\text { Cronbach's } \\
\text { alpha }\end{array}$ & $\begin{array}{l}\text { Floor } \\
\text { n }(\%)\end{array}$ & Chi-square & $\begin{array}{l}\text { Ceiling } \\
\mathrm{n}(\%)\end{array}$ & Chi-square \\
\hline $\mathrm{PF}$ & $42.37 \pm 34.37$ & 40 & $0-100$ & 0.95 & $41(20)$ & \multirow{2}{*}{$\mathrm{p}=0.096$} & $11(5.4)$ & \multirow{2}{*}{$\mathrm{p}=0.020$} \\
\hline PA & $62.25 \pm 24.81$ & 62 & $20-100$ & 97 & $6(2.9)$ & & $12(5.9)$ & \\
\hline SF & $52.07 \pm 31.02$ & 50 & $0-100$ & 0.60 & $20(9.8)$ & \multirow{2}{*}{$\mathrm{p}<0.001$} & $27(13.2)$ & \multirow{2}{*}{$\mathrm{p}=0.004$} \\
\hline SFR & $56.08 \pm 26.20$ & 53 & $20-100$ & 92 & $25(12.2)$ & & $18(8.8)$ & \\
\hline VT & $45.24 \pm 22.50$ & 45 & $0-100$ & 0.65 & $3(1.5)$ & $* p=0.39$ & $5(2.4)$ & ${ }^{*} \mathrm{p}=0.019$ \\
\hline $\mathrm{MH}$ & $62.30 \pm 19.41$ & 60 & $0-100$ & 0.59 & 0 & \multirow{2}{*}{$\mathrm{p} p=0.005$} & $4(2.0)$ & \multirow{2}{*}{${ }^{*} \mathrm{p}=0.434$} \\
\hline M & $61.85 \pm 26.25$ & 60 & $20-100$ & 83 & $15(7.5)$ & & $27(13.2)$ & \\
\hline \multicolumn{9}{|l|}{ SF-36 } \\
\hline Physical role difficulty & $36.22 \pm 43.40$ & 0 & $0-100$ & 0.92 & - & - & - & - \\
\hline \multicolumn{9}{|l|}{ Stroke } \\
\hline Language & $69.07 \pm 26.09$ & 73 & $20-100$ & 91 & - & - & - & - \\
\hline Vision & $73.63 \pm 24.70$ & 80 & $20-100$ & 78 & - & - & - & - \\
\hline Personality & $60.03 \pm 24.20$ & 60 & $20-100$ & 74 & - & - & - & - \\
\hline Thinking & $66.44 \pm 26.85$ & 70 & $20-100$ & 75 & - & - & - & - \\
\hline
\end{tabular}

Table 3. The relationship between the subdimensions of the scales

\begin{tabular}{|c|c|c|c|c|c|c|c|c|}
\hline $\begin{array}{l}\text { SF-36 } \\
\text { SS-QOL }\end{array}$ & $\mathrm{PF}$ & SF & VT & MH & $\begin{array}{l}\text { Physical role } \\
\text { difficulty }\end{array}$ & Pain & $\begin{array}{l}\text { Emotional role } \\
\text { difficulty }\end{array}$ & $\begin{array}{l}\text { General health } \\
\text { perception }\end{array}$ \\
\hline PA & $0.590^{*}$ & 0.476 & 0.428 & 0.307 & 0.518 & 0.462 & 0.485 & 0.457 \\
\hline $\mathrm{E}$ & 0.440 & 0.479 & $0.483^{*}$ & 0.353 & 0.410 & 0.460 & 0.514 & 0.422 \\
\hline M & 0.398 & 0.480 & 0.400 & $0.428^{*}$ & 0.343 & 0.386 & 0.430 & 0.512 \\
\hline Language & 0.360 & 0.382 & 0.394 & 0.355 & 0.358 & 0.360 & 0.447 & 0.418 \\
\hline Personality & 0.214 & 0.348 & 0.424 & 0.429 & 0.246 & 0.314 & 0.354 & 0.417 \\
\hline Thinking & 0.398 & 0.480 & 0.400 & 0.428 & 0.343 & 0.386 & 0.430 & 0.512 \\
\hline Total & 0.545 & 0.513 & 0.463 & 0.439 & 0.512 & 0.505 & 0.572 & $0.551^{*}$ \\
\hline
\end{tabular}




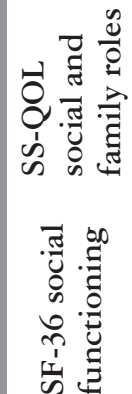

ז.

ปั่

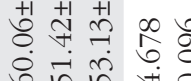

tit. nn

ते

ñ.

in in $\begin{array}{llll}\infty & \infty & \infty & 0 \\ 0 & \infty & 0\end{array}$

if $\infty$ o

तो त

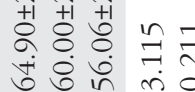

$\forall \infty$ \&

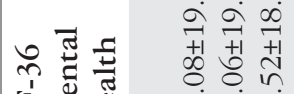

它 竞

तु

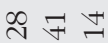

iิ

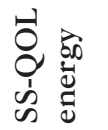

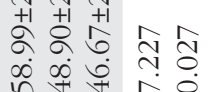

n०

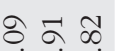

ते

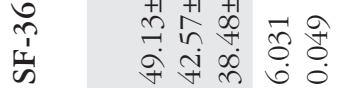

m to in

พี่

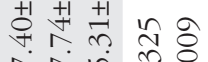

in in in

ริ

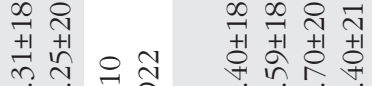

तु่

$\operatorname{1} 4$

ขิ

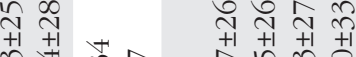

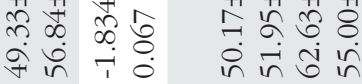

웅 m

तิ तें

T.

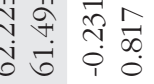

ㄴ.

in

श्रिथ

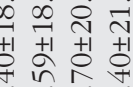

88 ชิ

in ?

$\exists \stackrel{5}{=}$

$6 N$

กิ

กै

가영

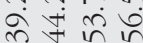

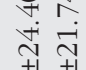

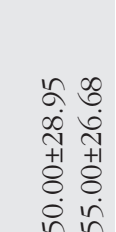

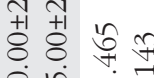

in

in in

กิ

กิ ขิ

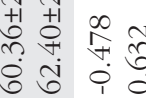

아 ㄴ??

से $\overrightarrow{े+}$

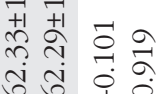

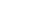

$\stackrel{m}{+}$

iे

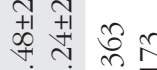

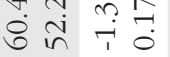

$\infty \stackrel{\circ}{\infty}$

กิ กิ

in

तु

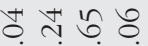

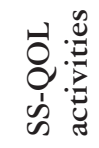

ते

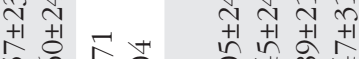

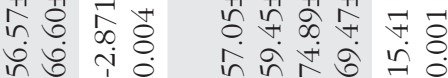

भे

nี थ

iั

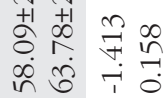

तi in

थิ่

+1 $\begin{aligned} & +1 \\ & 2\end{aligned}$

o

กิ

से के

कें चै

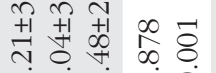

in

के $\infty$

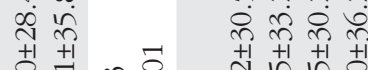

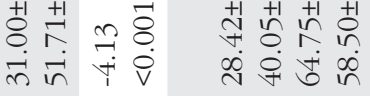

㟔导

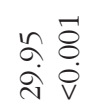

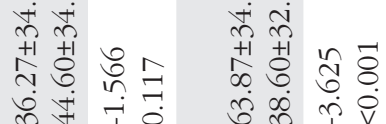

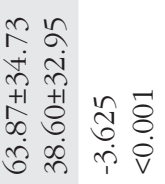

कf in

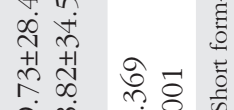
ते

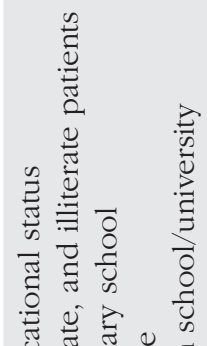

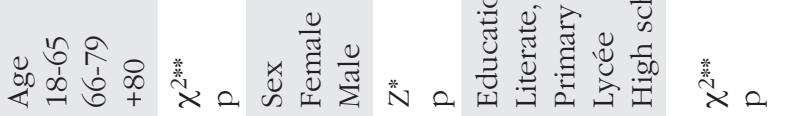

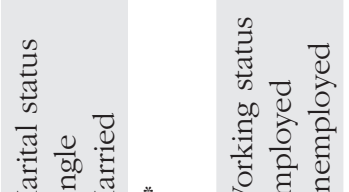

0
$y$
0
0
0
$\frac{1}{0}$
0
0
0
0
0
0
0
0
0
0 
assesses upper extremity functions, work/productivity, mobility, and physical status during self-care (27). The SF-36, on the other hand, evaluates the constraints in severe physical activities due to health problems in the PF subdimension. However, the fact that there were significant positive relationships in the four dimensions of the two scales and that their internal consistencies were close to each other, showed that both scales generally evaluated similar structural characteristics. 36

Cronbach's Alpha Coefficients of the SS-QOL and the SF-

One of the criteria showing that a measurement is made appropriately is its high reliability coefficient (28). In our study, Cronbach's alpha values ranged between $0.59-0.95$ in SF-36 and 0.74-0.97 in SS-QOL. These values are consistent with the literature and indicate a high level of internal consistency $(12,22)$.

In a study comparing the WHO Quality of Life BREF scales (WHOQOL-BREF) and SS-QOL, Cronbach's alpha values of SSQOL were found to range between 0.61-0.82 which are consistent with our study findings (31).

However, in our study, Cronbach's alpha values of the SS-QOL were relatively higher than for the SF-36. In one study, it was found that the SF-36 was not suitable for the assessment of patients with stroke and should be used for comparison between large groups. Reliability was found to be low, especially when the items were responded by the patient's relative(s) (32). However, it was found that the SS-QOL was moderately susceptible to changes in the first three months after stroke, but further research is needed regarding this issue (21). The fact that the internal consistency of the two scales was similar in their four parallel dimensions shows that the structural characteristics evaluated by these scales were similar.

\section{Correlation Values of Both Scales}

The highest correlation was found between similar subdimensions of the scales, specifically between SF-36 PF and SSQOL physical activities. This result shows that both subdimensions physically evaluate HRQoL in patients with stroke using the same criteria. The weakest correlation was found between SF-36 MH and SS-QOL-mood subdimensions. This was likely caused by the expressions of happiness-unhappiness included in the $\mathrm{MH}$ dimension.

In contrast to the findings in our study, in a study where WHOQOL-BREF and the SS-QOL were compared, a significant relationship was reported between the Psychological Health domain of WHOQOL-BREF and the T subdimension of SS-QOL (31). Similarly, in a study comparing SF-36 with another strokespecific scale [Stroke Impact scale (SIS)], it was reported that SIS assessed physical and SF better than the SF-36, and the use of items that measured these parameters in SF-36 was not appropriate for patients with stroke (17).

A moderate positive correlation found between the total score of the SS-QOL scale and all subdimensions of the SF-36, indicating that both scales could be used to assess QoL in stroke. However, in general, the average scores of the SS-QOL scale were higher relative to the SF-36 scale, which could be interpreted as the SS-QOL being more appropriate for these patients. In addition, because the items of the disease-specific scales better describe the disease in question; the use of disease-specific scales was recommended in these studies (17).
The Comparison of the SS-QOL and SF-36 According to Sociodemographic Characteristics

When HRQoL was examined in patients with stroke according to demographic characteristics, some differences in some domains were noted between these two scales. A statistically significant difference was detected in the energy subdimension relative to educational status subdimension of socio-demographic characteristics in the SF-36 scale in contrast to the SS-QOL scale $(\mathrm{p}<0.05)$ (Table 4$)$. When general QoL was evaluated using the SF-36, it was seen that the youth and men were better at social activities, high school graduates received higher scores in the Energy subdimension, and employees fared better in physical energy and SF. When QoL was evaluated using the SS-QOL, it was seen that the energy of lycée graduates was at a higher level.

The distributions of subdimension and total scores of both scales according to demographic characteristics were comparable. In other words, the parameter had a high average score in both SS-QOL and SF-36 scales. The differences in the different subdimensions of the two scales according to demographic characteristics may be because the SF-36 provides an overall assessment of QoL. However, the SS-QOL is disease-specific, and it rather focuses on the effect of the disease on the activity, energy, mental status, and social status of patients with stroke (17).

The mean scores of relatively younger patients in all age groups were higher in all similar dimensions of both scales than the other age groups. This result can be interpreted as the adaptation of young people to the disease was better and that the state of being more active in their daily lives physically, psychologically, and socially continued throughout the disease process. However, in contrast to our study, in a study, it was reported that the average scores of patients aged 70 years and over in terms of self-care, mobility, upper extremity functioning, family role and social role increased with increasing age (31). SF-36 scores were lower in all similar subdimensions compared with the SS-QOL. This decrease was mostly seen between PF and PA, which may be because the activities discussed in the PF dimension of SF-36 are mostly out-of-home activities and that patients with stroke have difficulty performing these activities. However, SS-QOL-PA dimension mostly evaluates self-care and in-home activities.

\section{Study Limitations}

There are some limitations to this study. First, the research data are confined to patients with stroke hospitalized in the neurology service of a training and research hospital. Therefore, the study results can be generalized only to this patient group. Secondly, the periods after the acute phase of the disease are not included in the study. Another limiting factor was that aphasic patients, those with visual and hearing impairments with whom the exchange of information was impossible, and patients with musculoskeletal and nervous system disorders other than stroke were not included in the study. Finally, the severity of stroke was not graded.

\section{Conclusion}

The SS-QOL and SF-36 scales are reliable measurement tools that can be used to evaluate the QoL of patients with acute stroke. However, when similar subdimensions were examined, it was 
concluded that SS-QOL generally had higher mean scores, higher internal consistencies, and also a moderate correlation existed between similar subdimensions of both scales. Besides, the ceiling and floor values of both scales were similar except for PF and A subdimensions. In line with these results, the use of the diseasespecific SS-QOL scale is priorly recommended for the evaluation of the QoL of patients with acute stroke. It is also recommended that this study should be performed in different groups of patients with stroke, one month or longer after a stroke attack.

\section{Clinical Practice}

The SF-36 scale is currently used to assess the QoL of patients with stroke in Turkey (Topcu and P1nar, 2012). The results of this study showed that the use of the SS-QOL scale might be more appropriate, especially in patients with acute stroke. In addition, the Stroke-Specific QoL Scale (SS-QOL) will provide nurses with more objective information when evaluating the physical activity of the patients when compared with the SF-36.

What Does this Paper Contribute to the Wider Global Clinical Community

- The SS-QOL will provide nurses with more objective information when evaluating the physical activity of patients when compared with SF-36.

- In future studies, the use of the SS-QOL may be recommended for QoL assessment of patients with stroke.

Nurses can plan patient care based on more objective results.

\section{Ethics}

Ethics Committee Approval: Ethics Committee of Umraniye Training and Research Hospital was acquired (B.10.10TKH.4.34.H.GP.0.01/43).

Informed Consent: The purpose of the study was explained to the participants before their informed written consent was obtained.

Peer-review: Externally peer-reviewed.

\section{Authorship Contributions}

Concept: B.Ö., S.D., N.Z., Design: B.Ö., S.D., N.Z., Data Collection or Processing: S.D., B.Ö., Analysis or Interpretation: N.Z., B.Ö., S.D., Literature Search: B.Ö., N.Z., S.D., Writing: B.Ö., N.Z., S.D.

Conflict of Interest: No conflict of interest was declared by the authors.

Financial Disclosure: The authors declared that this study received no financial support.

\section{References}

1. World Health Organization (WHO). CVD Atlas (2012) Deaths from coronary heart disease. Accessed: 25/01/2018. Available from: http://www. who.int/cardiovascular_diseases/en/cvd_atlas_16_death_from_stroke.pdf

2. Jones SP, Jenkinson AJ, Leathley MJ, Watkins CL. A stroke knowledge and awareness: an integrative review of the evidence. Age Ageing 2010;39:1122.

3. Benjamin EJ, Blaha MJ, Chiuve SE, et al. Heart disease and stroke statistics-2017 update: a report from the American Heart Association. Circulation 2017;135:e146-e603.

4. Giray S. Evaluation of acute stroke. In: Karataş M, (ed). Nörolojide Acil ve Yoğun Bakım. Istanbul: Akademisyen Kitabevi, 2010:35-45.

5. Topçu S, Bölüktaş RP. İnmeli hastalarda yaşam kalitesi ve sosyal desteğin yaşam kalitesine etkisinin incelenmesi. Yeni Tip Derg 2012;29:159-164.
6. Lin KC, Fu T, Wu CY, et al. Psychometric comparisons of the stroke impact scale 3.0 and stroke-specificquality of life scale. Qual Life Res 2010;19:435443.

7. Laurent K, De Seze MP, Delleci C, et al. Assessment of quality of life in stroke patients with hemiplegia. Ann Phys Rehabil Med 2011;54:376-390.

8. Chou CY, Huang CY, Huang YJ, et al. Comparison of construct validity of two short forms of stroke-specific quality of life scale. PLoS One 2017;12:e0188478.

9. Wong GK, Lam SW, Ngai K, et al. Development of a short form of strokespecific quality of life scale for patients after aneurysmal subarachnoid hemorrhage. J Neurol Sci 2013;335:204-209.

10. Holmes S. Assessing the quality of life--reality or impossible dream? a discussion paper. Int J Nurs Stud 2005;42:493-501.

11. Hong E. Age differences in health-related quality of life among South Korean elderly. Res Rev J Nurs Health Sci 2015;1:34-39.

12. Zengin N, Ören B, Gül A, Üstündağ H. Assessment of quality of life in haemodialysis patients: a comparison of the Nottingham Health Profile and the short form 36. Int J Nurs Pract 2014;20:115-125.

13. Carod-Artal FJ, Egido JA. Quality of life after stroke: the importance of a good recovery. Cerebrovasc Dis 2009;27 Suppl 1:204-214.

14. Wong GK, Lee A, Wong A, et al. Clinically important difference of strokespecific quality of life scale for aneurysmal subarachnoid hemorrhage. J Clin Neurosci 2016;33:209-212.

15. Carod-Artal FJ, Trizotto DS, Coral LF, Moreira CM. Determinants of quality of life in Brazilian stroke survivors. J Neurol Sci 2009;284:63-68.

16. Hamza AM, Al-Sadat N, Loh SY, Jahan NK. Predictors of poststroke healthrelated quality of life in Nigerian stroke survivors: a 1 year follow-up study. Biomed Res Int 2014;2014:350281.

17. Lai SM, Perera S, Duncan PW, Bode R. Physical and social functioning after stroke: comparison of the stroke impact scale and short form-36. Stroke 2003;34:488-493.

18. Czechowsky D, Hill MD. Neurological outcome and quality of life after stroke due to vertebral artery dissection. Cerebrovasc Dis 2002;13:192-197.

19. Erban P, Woertgen C, Luerding R, et al. Long-term outcome after hemicraniectomy for space occupying right hemispheric MCA infarction. Clin Neurol Neurosurg 2006;108:384-387.

20. Williams LS, Weinberger M, Harris LE, Biller J. Measuring quality of life in a way that is meaningful to stroke patients. Neurology 1999;53:1839-1843.

21. Williams LS, Weinberger M, Harris LE, Clark DO, Biller J. Development of a stroke-specific quality of life scale. Stroke 1999;30:1362-1369.

22. Chou CY, Ou YC, Chiang TR. Psychometric comparisons of four diseasespecific health-related quality of life measures for stroke survivors. Clin Rehabil 2015;29:816-829.

23. Kring DL, Crane PB. Factors affecting quality of life in persons on hemodialysis. Nephrol Nurs J 2009;36:15-24,55.

24. Ogutmen B, Yildirim A, Sever MS, et al. Health-related quality of life after kidney transplantation in comparison intermittent hemodialysis, peritoneal dialysis, and normal controls. Transplant Proc 2006;38:419-421.

25. Ware JE Jr, Sherbourne CD. The MOS 36 item short form health survey (SF 36). I. conceptual framework and item selection. Med Care 1992;30:473483.

26. Pınar R. Sağ lık araştırmalarında yeni bir kavram: yaşam kalitesi, bir yaşam kalitesi ölçeğinin kronik hastalarda geçerlik ve güvenirliğinin sınanması. Hemşirelik Bülteni 1995;9:85-95.

27. Hakverdioğlu YG, Khorshid L. Turkish version of the stroke specific quality of life scale. Int Nurs Rev 2012;59:274-280.

28. Nunally JC, Bernstein ICH. Psychometric Theory. 3rd ed. New York: McGraw-Hill, 1994.

29. Acaray A, Pınar R. Kronik hemodiyaliz hastalarının yaşam kalitesinin değerlendirilmesi. CÜ Hemsirelik Yüksek Okulu Dergisi 2004;8:1-11.

30. Hsueh IP, Jeng JS, Lee Y, Sheu CF, Hsieh CL. Construct validity of the stroke-specific quality of life questionnaire in ischemic stroke patients. Arch Phys Med Rehabil 2011;92:1113-1118.

31. Odetunde MO, Akinpelu AO, Odole AC. Validaty and reliability of a Nigerian-Yoruba version of the stroke-specific quality of life scale 2.0. Health Qual Life Outcomes 2017;15:205.

32. Salter K, Jutai JW, Teasell R, et al. Issues for selection of outcome measures in stroke rehabilitation: ICF Participation. Disabil Rehabil 2005;27:507528. 